\title{
A MEDIATED VISION, A MEASURED VOICE: CULTURE AND CRITICISM IN WHITMAN'S PROSE
}

\author{
ROBERT L. PINCUS
}

[Y]ou, like so many others, never seem to have read his Democratic Vistas and other of his statements decrying the materialism, industrialism, etc. of which you name him the guilty and hysterical spokesman.

- Hart Crane, in a letter to Allen Tate, 13 July $1930 .{ }^{1}$

"IN NO LITERARY FORM, except our newspapers, has there been anything distinctively American," William Douglas O'Connor wrote in his monograph on Walt Whitman, The Good Gray Poet (1866)-that is, the poet's longtime friend and unwavering supporter added, until Whitman wrote the first American literary work to rival the Iliad and the Odyssey: Leaves of Grass. O'Connor's mention of newspapers, as he well knew, was of direct relevance to Whitman's literary background as well as a general comment on the state of American letters. Like his earlier articles, editorials and reviews, O'Connor surmised, Whitman's poetry had "evolved entirely out of our own polity and popular life." 2 But for Ralph Waldo Emerson, the most perceptive contemporary reader of the 1855 edition of Leaves of Grass, this populist sensibility was combined with the voice of the mystic. Whitman's book of poems, he asserted, was "a remarkable mixture of the Bhagvat-Geeta and the New York Herald." 3 If Whitman had been the journalist, by 1855 he had become-as his "great master" Emerson implied-the cosmic journalist tuning, as it were, his earlier prosaic notes to a more sublime pitch.

In his earlier journalism, however, he had often turned polemical, editorializing on the widest range of subjects-from, say, civic issues to American literature-particularly in his position as editor of the Brooklyn Daily Eagle during 1846 and 1847 . Even at this early juncture, during his preliterary career as a writer, he composed passages of realistic scrutiny and others of idealistic futurism which he would later fuse into the contrapuntal pattern of his post-Civil War prose. In "Morbid Appetite for Money," an editorial dated 5 November 1846, Whitman complained of "the quackery of the thousand imposters of all descriptions who swarm through the land." But in other pieces, such as "Independent American Literature," published on 10 February 1847, he asserted, "We have every faith in the eventual justice and perceptions of the American people" - which, he added, would eventually produce both a genuine American literature and an audience commensurate with it. ${ }^{4}$ 
But it wasn't until 1867 that Whitman-encouraged by the owners and editors of Galaxy magazine, William C. and Francis P. Church-combined his reservations about America's present state and his hopes for its future into a single extended essay on the state of American literature and culture. "Democracy," as he called it, originated with the Churches' request for an essay that answered Thomas Carlyle's strident charges against democracy in his essay, "Shooting Niagara: And After?," which had appeared in the 16 August 1867 issue of the New York Tribune. ${ }^{5}$

Greatly troubled by the implications of both Lincoln's Emancipation Proclamation and England's Parliamentary Reform Bill of 1867 (which enfranchised the urban working class), the British essayist sounded his warning metaphorically, stating that Western Civilization was "shooting Niagara, to the bottom." To his way of thinking, freeing "Niggers" and enfranchising working class "rabble" were destructive acts against civilization. Hence, Carlyle reiterated arguments he had earlier formulated in On Heroes, HeroWorship and the Heroic in History (1841) and Past and Present (1843). He called for a reassertion of the power of the aristocracy (in politics and industry), and the glorification of lofty heroism in art by the literary Aristos. Without the domination of this "Aristocracy of Nature," Carlyle lamented, democracy would "go the full length of its course, towards the Bottomless or into it."

As the unequivocal spokesman for the grandness of democratic culture in the 1855 Preface and the initial editions of Leaves of Grass, Whitman initially thought to refute Carlyle's arguments in an unequivocal manner. But, in the process of defending the "twin sisters," democracy and America, Whitman openly acknowledged some of the "sad, serious truths" of Carlyle's critique of the democratic populace; "I had more than once been in the like mood," he would comment in a note to the expanded version of "Democracy," Democratic Vistas (1871). ${ }^{7}$

While admitting such truths were to be considered, Whitman countered, "Yet there are other, still deeper, amply confronting dominating truths." And these truths, he emphatically added, would come to exist "in the highest form of interaction between men and their beliefs." 8 American literature, in turn, would represent these interactions in an unimaginably grand fashion.

By working out his poles of disagreement and agreement with Carlyle's essay, Whitman had fastened upon the bifocal vision or contrapuntal voices that surface in all of his major pieces of cultural and literary criticism of the next three decades. In writing "Democracy," he had seized upon the newly achieved critical vision and voice he had adumbrated in his journalism, but thwarted in the process of forging the persona of Leaves of Grass. The distinctiveness of this critical voice, as one distinguishable from that of his poetry, hasn't received enough attention in our criticism. For example, Alfred Kazin, in a fairly recent article on Democratic Vistas, argues, "It is his poetry in a slightly lower voice."9 But such an argument overemphasizes the 
celebratory voice of Whitman's prose. In order to fully appreciate the heroic courage of his persevering belief that higher truths of democracy's future would supersede the sordid realities of the prosaic present, we must pay more attention to the way these voices or visions alternate in his literary and cultural criticism.

Even before Whitman had written the first poems for Leaves of Grass, he hints in "Democracy," he had taken stock of these sordid realities. "Once before the war, I, too, was filled with doubt and gloom," he candidly admits. In this first post-Civil War essay, he does distance himself from the expression of these doubts, since they are attributed to an unnamed foreign traveler. But they nevertheless foreshadow his directly expressed criticism in Democratic Vistas:

I have travelled much in the United States, and watched their politicians, and listened to the speeches of the candidates, and read their journals, and gone into the public houses, and heard the unguarded talk of men. And I have found your vaunted America honeycombed from top to toe with infidelism, even to itself and its own programme, I have marked the brazen shell faces of succession and slavery gazing defiantly from all the windows and doorways. I have everywhere found, primarily thieves and scalliwags arranging the nominations to offices themselves. I have found the North just as full of bad staff as the South. . . I I have noticed how the millions of sturdy farmers and mechanics are thus the helpless supplejacks of comparatively few politicians. And I have noticed more and more, the alarming spectacles of parties usurping the Government, and openly and shamelessly wielding it for party purposes. ${ }^{10}$

Here, and in the expanded form of Democratic Vistas, Whitman did indeed anticipate the postwar criticisms of America developed in the work of such writers as Henry Adams, Samuel Clemens, and John de Forrest. Like Adams, he asserted that Americans were ignorant of their own ignorance, even as he held out more hope for their edification and improvement than any of his fellow social critics. ${ }^{11}$ But his hopes notwithstanding, Whitman continued to castigate Americans for their contemporary shortcomings. By the time he had incorporated "Democracy"-with many revisions-into Democratic Vistas, Whitman had gained enough confidence in his powers as a cultural critic to express similar complaints in a direct, observational voice. The traveler's complaints would appear near the end of the later essay, but almost at the outset, he describes with great dissatisfaction the "petty grotesques, malformations, and phantoms" that seem to populate New York and Brooklyn while he is vacationing there in September 1870. And in a tone as stringent as Carlyle's, he condemns these city dwellers; they possess, he asserts, "a range of manners, or rather lack of manners. . . probably the meanest to be seen in the world."12

But for Whitman, it is feudal culture in its "five-hundredth importation" rather than democracy that is responsible for these deformed beings. These are not the types of a democratic culture, but those of a once glorious feudal 
culture that has outlived its usefulness and thus degenerated. If Carlyle expresses, for Whitman, "certain judgments from the highest feudal point of view," it is still feudal culture which is the enemy in the New World. "The United States," Whitman dramatically exclaims, "are destined either to surmount the gorgeous history of feudalism, or else prove the most tremendous failure of time."13 In a manner foreign to his poetry, then, he launches an attack on the domination of feudal culture in America. Though differently motivated, Whitman's chief target, like Twain's, is the romance. Both European and American writers, he complains, concoct "The same endless thread of tangled and superlative love story. . . . The costumes brought down to date, the seasoning hotter and more varied, the dragons and ogres left out, but the thing, I should say, has not advanced-is just as sensational, just as strain'd." The thing, it seems, was for Whitman the genre, and genres had to advance as a sign that the culture itself was advancing. Thus, the fate of a literature and the fate of a culture were inextricably intertwined; and, in turn, the stagnation of a literary genre would be reflected in the character of those who produced it. According to Whitman, then, it was only logical, and indeed inevitable, that romances were produced by "a parcel of dandies and ennuyees, dapper little gentleman from abroad." 14

Using Whitman's own term, one can say he is using his "moral microscopic vision" as a prerequisite to his sounding of this critical voice against these manifestations of feudalism; and when applying this mode of seeing, he is scrutinizing the American scene in all its most prosaic details. In Whitman's own often quoted words, "Using the moral microscope upon humanity, a sort of dry and flat Sahara appears, these cities crowded with petty grotesques, malformations, phantoms, playing meaningless antics."15 $\mathrm{He}$ reserved this type of moral criticism for his cultural and literary criticism. It is the negative analogue to his lofty vision of a culture of democracy and science (i.e., progress) that underlies Leaves of Grass-sounded from the first, often repeated inscription to the poems of the "Last Annex." As late as 1892, in "The Commonplace," he would write, "The democratic wisdom underneath, like solid ground for all."16 Whitman never abandoned such wisdom in his criticism; but even as he outlined his "programme of culture" in Democratic Vistas, which was designed to shatter the feudal shackles which suppressed a budding American culture, his counterpoised voice, the voice of his cultural criticism, chipped away at those threatening shackles.

It is not coincidental, then, that Whitman first uses the word "culture" in Democratic Vistas, as Roy Harvey Pearce has noted. ${ }^{17}$ The development of both his moral microscopic vision and his voice of cultural criticism occurs at the same moment in his career as he introduces the word into his vocabulary and articulates his "programme of culture." "Speech is the twin of my vision," Whitman had first declared in the "Song of Myself" of 1855, and he applied this notion in Democratic Vistas as well. ${ }^{18}$ 
Yet Whitman introduced the word "culture" into his vocabulary reluctantly; it put him, as his argument had it, "in close quarter with the enemy." The enemy, of course, was feudal culture in all its American manifestations, both domestic and imported. But the word was acceptable, he added, because he invoked it to make "a radical change of category," to raise the possibility of what Susan Sontag has called his idea of "the Great American Cultural Revolution." 19 And, though she refers directly to his 1855 preface, the explicit description of his potential revolutionaries occurs in Democratic Vistas:

I should demand a programme of culture, drawn out, not for a single class alone, or for the parlors, or lecture-rooms, but with an eye to practical life, the west, the working-men, the facts of farms and jackplanes and engineers, and of the broad range of the women also of the middle and working strata, and with reference to the perfect equality of women. ${ }^{20}$

Here were the types of Whitman's new, as-yet-to-be-created democratic culture; not the types of a refined gentility, but those of a culture of virility. These were the types of "well-begotten selfhood," those he termed the selves of Personalism. Thus, working with the notion that America must become a land of fulfilled selves, equal by virtue of their respective fulfillment of individual potentialities, he in turn measured the present according to emphatically high standards. Democracy, he wrote, "is a word the gist of which still sleeps. . . . It is a great word, whose history, I suppose, remains unwritten, because that history has as yet to be enacted."21 As Whitman gauged the range of the American vistas in 1871, he surmised that the democratic potentialities of those selves outside the halls of refined culture hibernated.

But he also surmised that these American types needed only a culturemaking argument to tap their democratic potential. For Whitman, his concept of Personalism, which argued for a land of fulfilled selves, provided such an argument. As critical as Whitman was of the American masses, he made it clear that his moral microscope was trained on them in the service of his hope. A literary work, he stated elsewhere, "is false if it deals with abnormal or grotesque characters," and he chided writers of the "local-color school" such as George Washington Cable, George Washington Harris, and Mary Wilkins for not seeming "content with the normal man."22 But the discussion of these grotesques was appropriate to Democratic Vistas, he seemed to say, because this was not his poetry, but a call for that poetry and that culture of democracy.

Whitman's call was actually an exhortation to fulfill his grand schema of America's progressive development. In Whitman's estimation, the first two stages of progress - the establishment of an appropriate political foundation and material prosperity-had already been fulfilled. It was the third and unfulfilled stage, however, for which he had written the essay at all-he had written it to articulate his notion of "a sublime and serious Religious 
Democracy sternly taking command, dissolving the old, sloughing off surfaces, and from its own interior and vital principles, reconstructing, democratizing society." 23 This is the notion he hoped to communicate to those practical types he had enumerated. It was also, as Whitman himself realized, an American society he had generated from his own imagination, a society that existed only in his vision. But once envisioned and articulated, it was also possible. As he put it:

There is, in sanest hours, a consciousness, a thought that rises, independent, lifted from all else, calm, like the stars, shining eternal. This is the thought of identity-yours for you, whoever you are, as mine for me. Miracle of miracles, beyond all statement, most spirtiual and vaguest of earth's dreams, yet hardest basic fact, and only entrance to all facts. ${ }^{24}$

Imaging the possibility of a society of fulfilled selves, Whitman sounded these most lyrical notes of Democratic Vistas - the notes that punctuated his song of Personalism. This is the animating theme of his essay, even as he admits it is an almost intangible ideal rather than a formulated philosophy. But Whitman's lyrical passage also asserts that it could become a fact as actual as any, if only his reading audience saw fit to implement his "programme."

For Whitman, the very ideal of Personalism, however intangible, was sufficient; it justified the strategy of contrapuntal voices and bifocal vision that pervade this essay and such later pieces of criticism as "A Backward Glance O'er Travel'd Roads" (1888) and "American National Literature" (1891). In Democratic Vistas, he had attacked the perceived enemies with greatest vehemence. "Do you call those genteel little creatures American poets? Do you term that perpetual, pistareen, paste-pot work, American art, American drama, taste, verse?" Whitman asks in a rhetorical fashion-and the all-inclusive negative answer to these questions provided the underlying perception of his cultural and literary criticism that followed. ${ }^{25}$

His largest affirmative and constructive reply, of course, was Leaves of Grass. In "L. of G's Purport," which initially appeared as a poem in Goodbye My Fancy (1891), the first two lines read: "Not to exclude or demarcate, or pick out evils from the formidable masses (even to expose them) / But add, fuse, complete, extend-and celebrate the immortal and the good." 26 This was a fairly straightforward, retrospective statement of the unifying vision of Leaves of Grass. He celebrated the good over and above evil; even if evil was not to be excluded from his poetry, it was to be subordinated to the good. And this idealistic, even heroic, vision of his art's task persevered, even while an ongoing critique of contemporary American culture served as a competing mode of expression during his post-Civil War years.

In his criticism, however, he discussed the consequences of the divergence between his vision of America and the nation's present condition. As democratic as Leaves of Grass was, he lamented, it was ultimately an 
avant-garde work. In "Splinters," a short prose piece also included in Goodbye My Fancy, he admitted as much:

While I stand in reverence before the fact of Humanity, the People, I will confess, in writing my L of G, the least consideration out of all that has had to do with it has been the consideration of "the public" - at any rate as it now exists. Strange as it may sound for a democrat to say so, I am clear that no free and original and lofty-soaring poem, or one ambitious of those achievements, can possibly be fulfill'd by any writer who has largely in his thought the public. . . .27

From Whitman's vantage point, it seems, his poems were written for the audience he envisioned and described, at selected moments, in Democratic Vistas; they were the audience that would populate the world of a democratic future, the world of "Religious democracy-still unborn and its history unwritten."

This world seemed increasingly out of reach, Whitman asserted in his criticisms of the 1880s and 1890s. He came to doubt that American culture was progressing toward a state of spiritual fulfillment (i.e., his third stage of development); perhaps it was simply mired in its adoration of Mammon. In regard to literature, this problem posed a paradox. Even as scientific and industrial advancements of the 19th century made the transmission of serious democratic literature to a wider audience possible - a potentially constructive phenomenon, in his estimation - it seemed to work against this possibility; Americans, he observed, were deluged with subliterary and derivative literary publications. Misquoting Margaret Fuller in two separate pieces, "Book Classes - American Literature" (1882) and "American National Literature," he made this complaint: "It does not follow, because the United States print and read more books, magazines, and newspapers . . that they really have therefore a literature." 28 As early as 1871 , of course, Whitman had concluded that they didn't. They were more concerned with "current inventions and productions," as he stated in Democratic Vistas - that is, they were mired in the second stage of democratic cultural development.

It was cause for further disillusionment, he lamented, that in the years since Democratic Vistas had been written, American culture had advanced no further. A large audience for Leaves of Grass had not arisen, nor had other poets and artists of the ilk he had hoped for and called for in the years that immediately followed the Civil War. It was these sad realizations which informed "A Backward Glance O'er Travel'd Roads." Here, his voice of cultural criticism assumed its most candid tone, reflecting on the status of his " $\mathrm{L}$ of G" in relation to contemporary America. To some degree, he had even begun to doubt the very "mission" of Leaves of Grass, questioning whether, knowing what he did in the late 1880 s, he would have attempted to assume the role of the poet of democracy and scientific culture. Reflecting on the years in which Leaves of Grass first evolved, Whitman wrote: 
Modern science and democracy seem'd to be throwing out their challenge to poetry to put them in its statements in contradistinction to the songs and myths of the past. As I see it now (perhaps too late,) I have unwittingly taken up that challenge and made an attempt at such statements - which I certainly would not assume to do now, knowing more clearly what it means.

In making this claim, he questioned the validity of his social and cultural mission, as outlined in Democratic Vistas and poeticized in Leaves of Grass. Elsewhere in the essay, he would continue to argue for the validity of his poetry, but only for a future public; at present, it had only historical and autobiographical importance. ${ }^{29}$

Whitman had not truly altered the identity of the persona of Leaves of Grass, even if he brooded over the stagnation of American culture. 'Leaves of Grass'...," he asserted, "has mainly been ... an attempt, from first to last, to put $a$ Person, a human being (myself, in the latter half of the Nineteenth Century in America) freely, fully and truly on record." 30 He was still a "myself" that, as Whitman's capitalization and italization of "person" indicates, was a specimen or archetypal democratic citizen - the "I" he had forged in "Song of Myself." He was, however, cut off from the hope that the value of his vision and his voice would be heard in his own time: the "simple, separate person" was cut off from the actual "en-masse." "From a wordly point of view," he reflected, "Leaves of Grass' has been worse than a failure-that public criticism on the book and myself as author ... shows marked anger and contempt more than anything else." 31 This no longer surprised him, since America had been "retarded and jeopardized"; democracy had been reduced "to a dead level." ${ }^{2}$ But in 1888 , more than 1871 , his anger over this sad state of affairs was subdued. He partially contented himself with thoughts that Leaves of Grass was his "definitive carte visite to the coming generations of the New World." 33 To emphasize this point, Whitman would reiterate later in the essay, "My volume is a candidate for the future." 34

America, stagnating, as he saw it, beneath the suffocating weight of Old World culture, had relegated him to the role of stranger instead of spokesman. And yet, Whitman consoled himself, "the strongest and sweetest songs yet remain to be sung." If his own songs only anticipated these, still, when other worthy examples came forth, the value of his "calling card" would be recognized.

"My Book and I," Whitman mused of Leaves of Grass, "what a period we have presumed to span!" 35 Yet as the United States took a different course from the one Whitman had envisioned for it, he had looked for a means by which to express his disapproval for its prodigal ways. The overarching theme of Leaves of Grass, as Whitman saw it, denied such criticism within its parameters of vision, fashioning an ideal history of the self in the America of 1855 to 1892 . In his literary and cultural criticism, however, he found a form to fit his microscopically attuned eye and his castigating voice-both of 
which had little, if any, place in his poetry. Even in this prose genre, he never entirely abandoned his idealistic democratic futurism; but it is mediated by his observations of America's failings in the post-Civil War era, providing the contrapuntal movement of idealism and realism that characterizes these essays. In these writings, he articulated the vision of his less than specimen self, the more prosaic Whitman who lived from day to day as he fashioned his "L of G" - that expression of his more sublime self which he hoped would outlive his days.

\section{The University of Southern California}

\section{NOTES}

1 Brom Weber, ed., The Letters of Hart Crane (Berkeley: University of California Press, 1952), p. 354.

2 William O'Connor, The Good Gray Poet, in A Century of Whitman Criticism, ed. Edwin Haviland Miller (Bloomington: Indiana University Press, 1969), pp. 23-24.

3 Ralph Waldo Emerson, as quoted in F. O. Matthiessen, American Renaissance: Art and Expression in the Age of Emerson and Whitman (Oxford: Oxford University Press, 1941), p. 526.

4 Walt Whitman, "Morbid Appetite for Money," and "Independent American Literature," in Gathering of the Forces, ed. Cleveland Rodgers and John Black (New York: G. P. Putnam's Sons, 1920), 2:131, 241.

5 For an account of both the genesis and reception of "Democracy," see Gay Wilson Allen, The Solitary Singer: A Critical Biography of Walt Whitman (New York: New York University Press, 1967), pp. 389-394.

6 See Thomas Carlyle, "Shooting Niagara: And After?" in Critical and Miscellaneous Essays, Vol. 16 of The Works of Thomas Carlyle (Complete)(New York: Peter Fenelon Collier, 1897), p. 589 , et passim.

7 Walt Whitman, Democratic Vistas, in Prose Works 1892, ed. Floyd Stovall (New York: New York University Press, 1964), 2:375.

8 Walt Whitman, "Democracy," in Democratic Vistas 1860-1880, ed. with an introduction by Alan Trachtenberg (New York: George Braziller, 1970), p. 363.

9 Alfred Kazin, "Democracy According to Whitman," Commentary 61 (June 1976), 52.

10 Trachtenberg, p. 362.

11 See Henry Adams, The Education of Henry Adams, ed. Ernest Samuels (Boston: Houghton Mifflin Co., 1973), p. 237. I have in mind Adams's comment in the chapter entitled "Chaos" (1870), that "the scholar finds himself jostled by a crowd of men [i.e., American men] who seem to be ignorant that there is a thing called ignorance."

12 Whitman, Prose, 2:372.

13 Whitman, Prose, 2:363.

14 Whitman, Prose, 2:408.

15 Whitman, Prose, 2:371-372. 
16 Walt Whitman, Leaves of Grass, Comprehensive Reader's Edition, ed. Harold W. Blodgett and Sculley Bradley (New York: New York University Press, 1965), p. 554.

17 See Roy Harvey Pearce, "Whitman and Our Hope for Poetry," in Historicism Once More: Problems and Occasions for the American Scholar (Princeton: Princeton University Press, 1969), pp. 341-342. Pearce also informs us that Whitman made notes for an unwritten essay, which was to be called "The Theory of Culture," during the same years in which he was composing Democratic Vistas.

18 Whitman, Prose, 1:55.

19 See Susan Sontag, "America, Seen Through Photographs, Darkly," in On Photography (Farrar, Straus and Giroux, 1975), p. 27 et passim. Although Sontag's primary concern in this essay is American photography, she also offers suggestive comments on the ambitious scope and inevitable failure of Whitman's cultural program.

20 Whitman, Prose, 2:396.

21 Whitman, Prose, 2:393.

22 Walt Whitman, as quoted in Matthiessen, p. 603.

23 Whitman, Prose, 2:410.

24 Whitman, Prose, 2:394.

25 See Whitman, Prose, 2:388-389.

26 Whitman, Leaves of Grass, p. 555.

27 Whitman, Prose, 2:677.

28 See Whitman, Prose, 2:666-667. Stovall informs us that neither version is a correct citation of Margaret Fuller's words; in her essay, "American Literature" (1846), the sentence upon which Whitman models his own states: "For it does not follow because many books are written by persons born in America that there exists an American Literature." See Prose, 2:539 and 538-539n.

29 Whitman, Prose, 2:715.

30 Whitman, Prose, 2:730-731.

31 Whitman, Prose, 2:712-713.

32 Whitman, Prose, 2:726. See Pearce, Historicism, 335; one of Whitman's great post-Civil War insights, he asserts, is that "producers were increasingly bowed under the weight of their products." Here, Pearce echoes Crane's view, set forth in the 13 July 1930 letter to Allen Tate, of Whitman as the opponent of excessive materialism. This opposition, which is present in Democratic Vistas, was to become more explicit in "Book Classes-American Literature," "A Backward Glance O'er Travel'd Roads," and "American National Literature."

33 Whitman, Prose, 2:712.

34 Whitman, Prose, 2:730.

35 Whitman, Prose, 2:716. 